\title{
El portazo y el perro
}

Keywords: domésticos; maltrato; violencia; machista

Un portazo seco. Sin volver la cara. Desde el extremo del pasillo, con sueño aún en los ojos, le había preguntado, ¿te vas?. Y la respuesta fue el ruido de la puerta a sus espaldas. Unos minutos antes le había explicado -pedido disculpas- por haber llegado tarde la noche anterior, sin avisar, que no se había dado cuenta de la hora y era verdad. Y también que le había telefoneado al trabajo porque, una vez más, no había descolgado el móvil antes sus llamadas. Encima de su mesa de trabajo, por la manyana, había colocado un ramo de anémonas frescas, las flores favoritas de él. Ni las había mirado, ni le había dado las gracias.

Mutismo, desabrimiento en las respuestas, malas caras, castigar con actitudes huidizas, desaparecer horas y horas, volver a entrar en la casa sin decir una palabra, mirar fíjamente la televisión mientras ella le hablaba. Y así muchos, muchos, muchos días, semanas, meses, años.

El circuito del desamor tiene siempre las mismas estaciones. Ella no las conocía. La primera vez que, despues de una bronca, por un motivo banal, amenazó con irse de la casa, con buscarse otro sitio para vivir, gritando que esa no era la vida que quería vivir, que allí no había nada suyo, llamando "puto perro", al perrito que la seguía a todas partes, la mujer se derrumbó en llanto, no pudo dormir, la garganta le presionaba y tartamudeaba al hablar. Fue la primera de muchas otras broncas, con los mismos ingredientes y siempre la amenaza latente de irse, de romper la relación, de gritarle que tenía deseos de autolisis, de irse con el coche y despeñarse por un acantilado, de quejarse de que, el que lo perdía todo era él, que ella le provocaba para que se encabronara y acabara marchándose, que era ella la culpable, que no entendía nada, que no se enteraba y que repetía siempre las mismas conductas.

El resultado fue la dependencia. Estar permanentemente angustiada por no saber qué cara pondría. Muchas cenas en silencio. Llamarle por teléfono y no obtener respuesta. Y no dar explicaciones. Nunca haber pedido disculpas. Siempre querer decir la última palabra, dar el portazo y desaparecer. Tras la puerta cerrada -al principio ella no lo había advertido-, el perro se quedaba quieto, mirando fijamente, los ojos asustados, con un ligero temblor. Se quedaba allí durante horas y no la seguía por la casa, que era lo habitual. Ayer sí se dió cuenta de esa actitud del perro, triste y desconcertada, y se vió reflejada en él.

Hay muchos niveles de maltrato. Las mujeres que sufren situaciones como las que acabo de describir, tienen que saber que manipular, las amenazas de abandono, el desprecio por los sentimientos o el sufrimiento, el desdén ante los intentos de acercamiento, el victimismo y la frialdad, los insultos o la violencia contra los animales de compañía, también forman parte de las conductas que conforman el perfil del maltratador. Quizá nunca peguen en el cuerpo, pero sí en el corazón.

Recuperar la autoestima no es fácil, pero desde aquí, a todas las mujeres que se hayan sentido identificadas con algo de lo que he descrito, les animo a que reaccionen, a que salgan a la calle, a que vuelvan a frecuentar a sus amigas, a su familia, a que se concentren -aunque no puedan- en su trabajo, a que recuperen sus aficiones, a que piensen que las relaciones sanas están exentas de dependencia, a que luchen y a que no se resignen. Plantar cara a la mala vida. Hay otra mejor. No importa si hay que pasarla, digna y alegremente, sola. No hay putos perros, no hay que consentirlo, hay que reaccionar con dignidad, también por el perro. 
LA EDITORA

Teresa Giménez-Candela Catedrática de Derecho Romano Animal Law Profesor Universitat Autònoma de Barcelona 